\title{
VERSITA
}

Ekológia (Bratislava)

Vol. 32, No. 2, p. 242-247, 2013

doi:10.2478/eko-2013-0020

\section{WATER FLOW MODEL FOR THE HARRIER BASIN, KURDISTAN OF IRAQ}

\author{
AZAD J. SHARIF', ZIYAD R. ELIAS², MOHUMMED F. OMAR ${ }^{3}$ \\ ${ }^{1}$ Department of Geography, Salahaddin University, Erbil, e-mail: azad_sharif56@yahoo.com \\ ${ }^{2}$ Geomorphic Research, Salahaddin University, Erbil, e-mail: ziyadelias@yahoo.com \\ ${ }^{3}$ Remote Sensing Data Center, Mosul University, Mosul, Iraq; e-mail: mohummedz2004@yahoo.com
}

\begin{abstract}
Sharif A.J., Elias Z.R., Omar M.F.: Water flow model for the Harrier basin, Kurdistan of Iraq. Ekológia (Bratislava), Vol. 32, No. 2, p. 242-247, 2013.
\end{abstract}

\begin{abstract}
The study includes computer topographic and morphologic simulation of water flow produced using a watershed modelling system that uses hydrologic and physical data from the study area. The DEM module, TIN module, Map module and Hydrologic module were used in this study. A land use data, a soil data and rainfall data were used to produce a curve that illustrates quantity of water flow versus time of water flow across the Harrier basin. The calculated water loss rate can be attributed to a number of factors such as joints, faults, bedding and land use (agriculture and forest). Land use and soil characteristics are both important factors affecting water flow rates. The climate in the Harrier basin is semi-arid. Simulated flow data indicate that the top flow rate is 32 $\mathrm{m}^{3} / \mathrm{s}$ and that water can reach to the basin outlet in 3 hours and 10 minutes.
\end{abstract}

Key words: Harrier, GIS, basin, valley, quantity of flowing water, flow time, water loss.

\section{Introduction}

A model is defined as a simple compound system in which the behaviour of this system is represented by number of equations with logical aspects and relations between the variables to predict the required results (Clarke, 1973). The aim of such a model is to optimally understand watershed performance and the effect of variations as well as to serve as a suitable tool designed to get specific data concerning water flow (Jianyao, 1998). Channels and channel starting points are mapped as those grid cells where the support area threshold is exceeded. This procedure has been widely used and is implemented in the Arc Info grid. An important question associated with this method is what support area threshold to use? A basin's hydrology depends on its geomorphic form as well as hill slope. Channel and ecological processes are active at different spatial and temporal scales (Vivoni et al., 2007). The study includes computer topographic and morphologic simulation of water flow produced using a watershed modelling system (WMS) that uses hydrologic and physical data from the study area. The WMS includes powerful tools designed to automate the modelling process. These tools include automated basin delineation, geometric parameter calculation, GIS overlay computation and cross-section extraction from terrain data. The aim of this paper is to focus on creating a hydrologic module and digital el- 
evation models (DEMs) in a GIS environment as well as to learn how the data can be used in conjunction with a WMS to run lumped-parameter hydrologic models. This type of process requires the use of physical characteristics such as curve of hydrograph, rate of water loss and the time needed to reach to the mouth of the Harrier basin area of $20.9 \mathrm{~km}^{2}$. Elevation data can be represented digitally in many ways, including a grid model, where elevation is estimated for each cell in a regular grid, a triangular irregular network and contours (James, Linda, 1997). The representation of the DEM as a grid is quite common, as this format lends itself well to computer computations. These techniques include DEMs, which can be used to extract flow direction and Arc View. GIS techniques were used to define the relationship between topography and state variables of geoprocesses (Tong, Chen, 2002); while WMS techniques helped to calculate water flow through the valley, as well as identify the land use and soil type in the area.

\section{Methods}

GIS programmes and elevation data in a grid format can be used to delineate drainage basins, create stream networks and compute drainage basin data. Once computed, several important variables, such as area, slope and run-off distances, can be determined for hydrological analysis. A DEM can be used to determine the hydrologic parameters of a watershed such as slope, flow accumulation, flow direction, drainage area delineation and stream network. TINs were derived from a contour map. Then, the (DEM) and Map Module were used to produce a digital map of the Harrier Basin. The digital map of the basin is three-dimensional.

The TIN and Hydrologic Module were used to produce a water flow curve for the study area and to calculate flow time. The curve requires the integration of four layers: (1) digitized 3-D contour map, (2) digitized land use map five groups (Table 1), (3) digitized soil coverage map (three groups A, B, and C (Table 2) and (4) daily local rainfall data. Land use and soil classes were also used in the computation of run-off use of the SCS Curve Number Method to calculate water loss. Supplemental data were collected on-site during the winter season (Fig. 1).

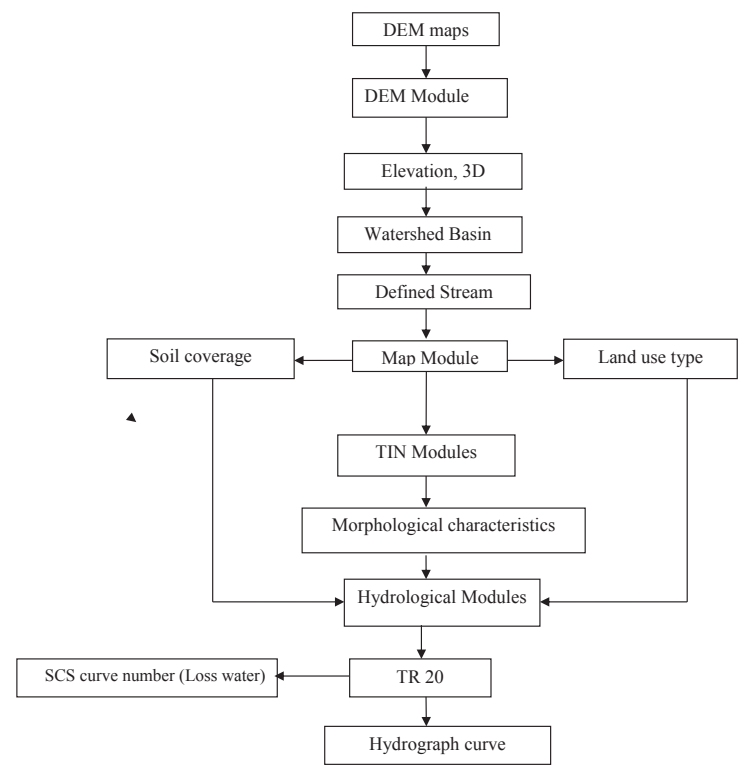

Fig. 1.WMS flow chart. 
Stream flow is one of the main manifestations of hydrologic conditions in drainage basins. Because streams are the foundation from which other information is georeferenced or derived, the quality of the original stream data influences the quality of subsequent data layers. Biological, physical and chemical conditions, including fish abundance, habitat types and dissolved oxygen concentrations, can be georeferenced to a stream layer. The study area lies in the higher fold zone in northern Iraq (Kurdistan of Iraq) where the mountain affects the shape of the stream in the middle and southern parts of the study area (Omar, 2005). Basin slope is $1.2711 \mathrm{~m}$, mean elevation is $477.08 \mathrm{~m}$ and sinuosity is $9.8 \mathrm{~m}$ (Table 1). Differences in stream slope manifest themselves in fluvial processes on hill slopes and in stream channels. It is important to properly map the physical extent of a stream and its tributaries within a study area. Figure 2 is an elevation map of the study area. The stream rises to flow at an elevation of $1200 \mathrm{~m}$ in the Harrier mountains. All elevations $(1100,1000,900$ and $800 \mathrm{~m})$ are located in the southern slope of this mountain range because this is where geomorphic processes can be best observed (denudation, erosion transport). Slope stability shown in these elevations in different failure types toppling, plane sliding and rock fall (Barzani, 2008). A break in the slope occurs at an elevation of $700 \mathrm{~m}$ due to gully erosion. The down-slope area is found at elevations of 600,500 and $400 \mathrm{~m}$. At these locations, sediments appear to yield to fluvial transport process.

T a b l e 1. Morphological characteristics of Harrier basin.

\begin{tabular}{|l|c|}
\hline Area $(\mathbf{k m})$ & 20.9 \\
\hline Average slope of basin $\mathbf{( m / m )}$ & 1.2711 \\
\hline Average overland flow distance $\mathbf{( k m})$ & 1003.49 \\
\hline Maximum flow gradient $\mathbf{( m / m )}$ & 0.3578 \\
\hline Length of basin $\mathbf{( k m )}$ & 20425.8 \\
\hline Maximum flow distance $\mathbf{( m / m )}$ & 27968.88 \\
\hline Sinuosity $(\mathbf{m s l} / \mathbf{l})$ & 9.8 \\
\hline Average elevation of basin $\mathbf{( m )}$ & 477.08 \\
\hline Maximum stream length $(\mathbf{m})$ & 22450.62 \\
\hline Maximum stream slope $\mathbf{( m / m )}$ & 0.0896 \\
\hline
\end{tabular}

$\mathrm{T} \mathrm{a} \mathrm{b} \mathrm{le} \mathrm{2.} \mathrm{Types} \mathrm{of} \mathrm{land} \mathrm{use} \mathrm{in} \mathrm{Harrier} \mathrm{basin.}$

\begin{tabular}{|l|l|l|}
\hline Location & Shape of surface & Type of land use \\
\hline Mountain & Dip slope & Little forest \\
\hline Hill slope & Variability & Bad land \\
\hline Harrier town & Sub-variability & Urban area \\
\hline Batas & Sub flat & Forest \\
\hline Plain & Flat & Agricultural \\
\hline
\end{tabular}

$\mathrm{T} \mathrm{a} \mathrm{b} \mathrm{le} \mathrm{3.} \mathrm{Soil} \mathrm{coverage} \mathrm{in} \mathrm{Harrier} \mathrm{basin.}$

\begin{tabular}{|l|l|}
\hline Layer & Location \\
\hline A & Batas, hill slope \\
\hline B & Plain \\
\hline C & Harrier Mountain \\
\hline
\end{tabular}

\section{Results}

Water flow is concentrated in channels, hence the drainage area contributing to each point in a channel may be quantified, while on hill slopes, flow is dispersed. The 'area' draining to 


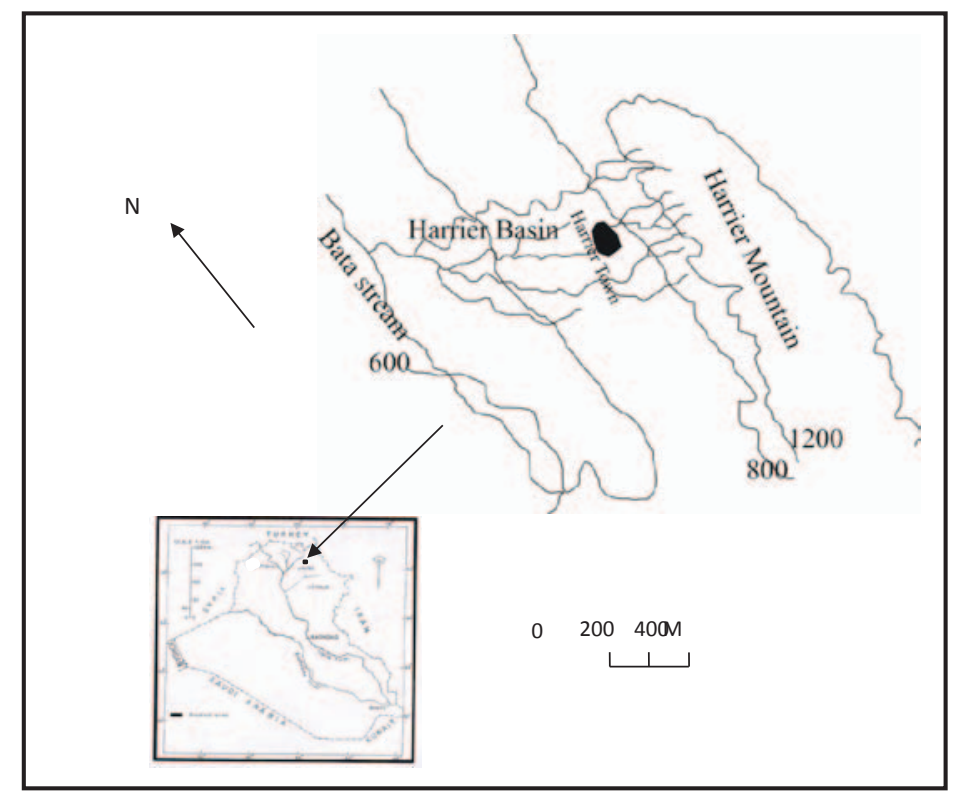

Fig. 2. Location of the study area in Iraq.

a given point is zero because the width of a flow path to a point disappears (Fagherazzi et al., 2004). In Table 3 , the watershed modelling programme used physical characteristics such as maximum flow slope $(0.3578 \mathrm{~m} / \mathrm{m})$ and total length $(20425.8 \mathrm{~m})$. The time of concentration for the study area was calculated by the modelling programme as 3.5 hours and 5 minutes. A long storm period produces significant flooding at the basin outlet, which increases erosion (a form of sediment transport) throughout all 3 hours. Figure 3 shows water flow versus time, starting from the Harrier Mountains to the point of confluence with Bata Stream (basin outlet). The quantity of water flow changes from the axial area of the Harrier Mountains, as it is fed back to the sub stream. The water flow rate starts at $5 \mathrm{~m}^{3} / \mathrm{s}$ in the Harrier Mountains at 1 hour and a half, and increases in the middle section of the basin to $32 \mathrm{~m}^{3} / \mathrm{s}$ at 2 hours and a half. This is because more sub streams affect Harrier Stream.

Overland flow and maximum flow distance are important for fluvial processes in the case of gully erosion. A large rainfall rate can overcome the soil's infiltration rate during a storm event (Solyom, Tucker, 2004). The rate of water loss during a storm is $47.05 \%$. This is due to four factors - joints and faults in the Harrier anticline as well as soil type and land use in the middle and southern parts of the basin. In the middle and southern parts of the basin, agriculture plays a role and the soil type is represented by two crops (A and B). All of the above factors lead to water loss in two areas - the first is the ground and second is the basin surface, which is used by agriculture.

As erosion advances, flood peaks increase in magnitude and decrease in response time, suggesting higher basin sensitivity to rainfall. Fluvial erosion leads to steeper slopes along 
the Harrier anticline channel interface, which affects the resulting hydrograph. Major soil erosion occurs in Layer C in the Harrier Mountains - called gully erosion. Other factors such as slopes, joints and faults featuring little vegetation also lead to the loss of this layer.

\section{Discussion}

Short water flow times are important for other types of studies - ones that deal with hazard flood maps. An entire event, from initial flow to drought, might take no more than a few hours. The town of Harrier will be in danger if the depth of rainfall is heavy because it is located in the south limb of Harrier mountain. This danger will be in the sub-basin because it flows from elevation 1200 to $800 \mathrm{~m}$ and it is short.

The variability surface with little forest is occurring in these elevations and more rainfall flowed from this elevation in the shape of gully erosion. Activity fluvial geomorphology is shown with feature of slope stability; however, the affect of fluvial process has appeared on the road of Harrier town during and after the storm such as sediment and rock. Lost forest in the Harrier Mountain and layer $\mathrm{C}$ soil are field back to global climate changes and human used these forests for life. So this cannot be safe from other processes such as rock fall and sediment yield.

\section{Conclusion}

The peak flow hydrograph, shape of hydrograph and time of peak flow are the most important parameters to predict flow hydrograph of flood. Morphologic, soil type, land use and rainfall data

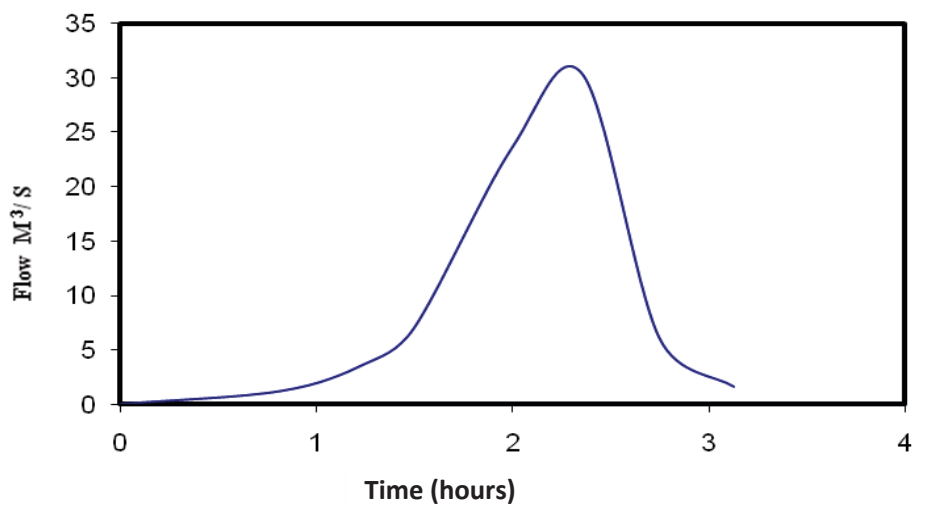

Fig. 3. Water flow versus time.

for the Harrier Basin were successfully used to analyse water flow rates. The run-off coefficient and peak discharge were calculated as well. Run-off and soil loss data for small drainage basins are becoming increasingly important as concerns about surface water quantity increase (Fig. 4). Water quantities in the Harrier Basin have changed over the last few years due to insignificant rainfall (one to three months). 
The 3-D model provides reliable data estimates. The Harrier basin has flowing water in the winter and is dry in the summer. The relationship between rainfall and run-off coefficients for the Harrier basin was shown by the infiltration process.

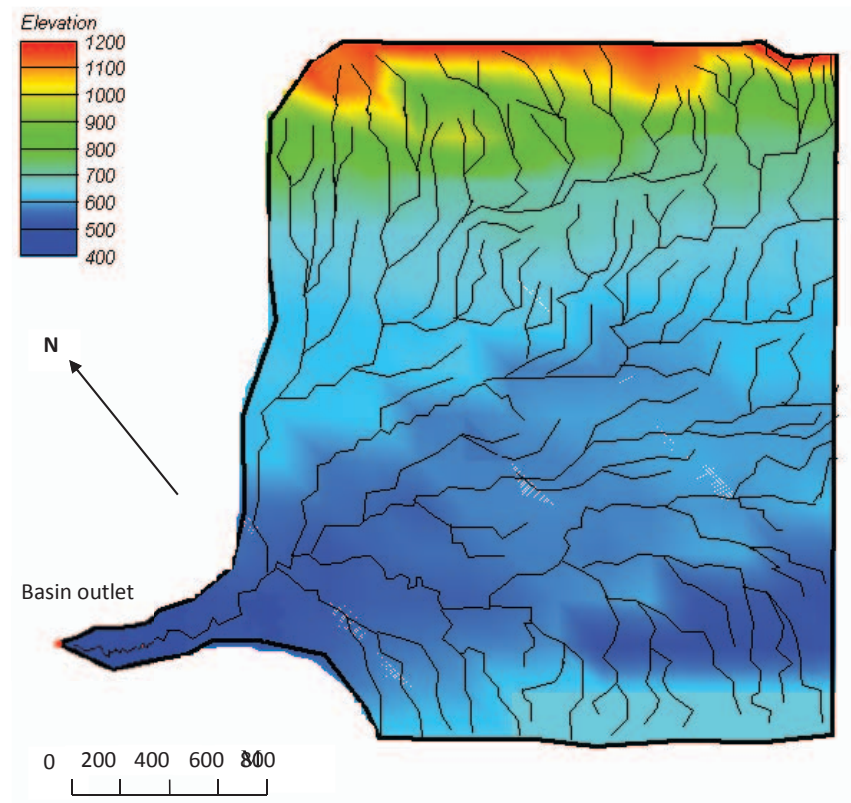

Fig. 4. Drainage basin with elevations.

\section{References}

Barzani, M.A.M. (2008). Engineering geology study of rock slope stability in harrier area Kurdistan region-Iraq. Unpublished MS thesis, Department of Geology, Salahaddin University, Erbil.

Clark, R.T. (1973). Mathematical models in hydrology. Food and Agriculture Organization of United Nations, Irrigation and Drainage, Rome, No. 19, p. 1-18.

Clarke, S. \& Burnett K. (2003). Comparison of digital elevation models for aquatic data development. Photogramm. Eng. Remote Sensing, 69, 1367-1375.

Fagherazzi, S., Howard, A.D. \& Wiberg P.Z. (2004). Modeling fluvial erosion and deposition on continental shelves during sea level cycles. J. Geophys. Res., 109, 1-16. DOI: 10.1029/2003JF000091.

James, R. \& Linda L. (1997). An evaluation of digital elevation models for upgrading New Zealand land resource inventory slope data. In Proceedings of GeoComputation (pp. 15-22).

Jianyao, C. (1998). The simulation of runoff using a time-area graph derived from DTM. J. ITC, 2, 113-117.

Omar, A.A. (2005). An integrated structural and tectonic study of the Binabawi-Safin-Rbadost region in Iraqi Kurdistan. Unpublished Ph.D. thesis, Department of Geology, Salahaddin University, Erbil.

Solyom, P.B. \& Tucker G.E. (2004). Effect of limited storm duration on landscape evoluation, drainage basin geometry, and hydrograph shapes. J. Geophys. Res., 109, 1-13. DOI: 10.1029/2003JF000032.

Tong, S.Y. \& Chen W. (2002). Modeling the relationship between land use and surface water quality. J. Environ. Manag., 66, 377-393. DOI: 10.1006/jema.2002.0593.

Vivoni, E.R., Istanbulluoglu, E. \& Bras R.L. (2007). A blueprint for an integrated watershed hydro-geomorphic modeling system. www.ees.nmt.edu/vivoni/2003paper_ICRW pdf.

WMS, 5. (1997). Watershed modelling system. Engineering Computer Graphics Laboratory. Brigham Young University. 